\title{
Representations of internationalisation at a Portuguese Higher Education Institution: From institutional discourse to stakeholders' voices
}

\author{
Mónica Lourenço, Ana Isabel Andrade \\ \& Michael Byram
}

\begin{abstract}
:
Internationalisation has become a major concern of higher education institutions around the world, featuring as a goal in their mission statements and agendas. Yet, the ways it is perceived and addressed vary greatly. In some cases, internationalisation is viewed as a service to export, whilst in other cases the focus falls on the acquisition and development of graduates' global and intercultural competences. This paper reports on a study that aimed to understand how internationalisation is perceived at a Portuguese Higher Education Institution. To achieve this goal institutional policy documents were collected, and semi-structured interviews were conducted with members of governing and coordinating bodies, as well as with academic and non-academic staff. Results from thematic analysis suggest that internationalisation is seen as a priority at the highest strategic level, being associated with a set of activities (student mobility, international research projects, and English-medium instruction) and with a set of desired outcomes (increased revenues and institutional visibility). Moreover, stakeholders consider internationalisation a valuable asset for the development of students' skills, expressing positive attitudes towards such initiatives as "internationalisation at home". Based on these findings, recommendations for a more comprehensive and sustainable internationalisation approach applicable to other contexts are put forward.
\end{abstract}

Keywords:

internationalisation; Portuguese higher education; social representations 


\title{
Representações de internacionalização numa instituição de ensino superior portuguesa: do discurso institucional às vozes dos atores
}

\begin{abstract}
Resumo: A internacionalização tornou-se uma grande preocupação das instituições de ensino superior em todo o mundo, figurando como um objetivo nas suas declarações de missão e agendas. Porém, a forma como a internacionalização é percebida e tratada é muito variada. Em alguns casos, a internacionalização é vista como um serviço para exportação; em outros casos, o foco recai sobre a aquisição e desenvolvimento de competências globais e interculturais pelos graduados. Este artigo apresenta um estudo que teve como objetivo compreender como e que a internacionalização é percebida numa Instituição de Ensino Superior Portuguesa. Para atingir esse objetivo, foram recolhidos documentos institucionais e foram realizadas entrevistas semiestruturadas a líderes institucionais, pessoal docente e não docente. Os resultados da análise temática sugerem que a internacionalização é vista como uma prioridade estratégica na instituição associada a um conjunto de atividades (mobilidade estudantil, projetos de investigação internacional e ensino através da língua inglesa) e a um conjunto de resultados desejados (maior retorno financeiro e visibilidade). Para além disso, os entrevistados consideram que a internacionalização pode ser um recurso valioso para o desenvolvimento de competências pelos estudantes, mostrando atitudes positivas em relação a iniciativas como a "internacionalização em casa". Com base nestes resultados, são apresentadas algumas recomendações para uma abordagem mais abrangente e sustentável de internacionalização, que podem ser aplicadas a outros contextos.
\end{abstract}

Palavras-chave: internacionalização; Ensino Superior português; representações sociais.

\section{Representaciones de internacionalización en una institución de educación superior portuguesa: del discurso institucional a las voces de los actores}

Resumen: La internacionalización se ha convertido en una gran preocupación de las instituciones de educación superior en todo el mundo, figurando como un objetivo en sus declaraciones de misión y agendas. Sin embargo, la forma como la internacionalización es percibida y tratada es muy variada. En algunos casos, la internacionalización es vista como un servicio para exportación; en otros casos, el foco recae sobre la adquisición y desarrollo de competencias globales e interculturales por los graduados. En este artículo se presenta un estudio que tuvo como objetivo comprender cómo es percibida la internacionalización en una institución de educación superior portuguesa. Para alcanzar ese objetivo, fueron recogidos documentos institucionales y se realizaron entrevistas semiestructuradas a líderes institucionales, personal académico y no académico. Los resultados del análisis temático sugieren que la internacionalización es vista como una prioridad estratégica en la institución asociada a un conjunto de actividades (movilidad estudiantil, proyectos de investigación internacional y enseñanza a través de la lengua inglesa) y resultados deseados (mayor retorno financiero y visibilidad). Además, los encuestados consideran que la internacionalización puede ser un recurso valioso para el desarrollo de competencias por los estudiantes, expresando actitudes positivas hacia iniciativas como la "internacionalización en casa". En base de estos resultados, se presentan algunas recomendaciones para un enfoque más amplio y sostenible de internacionalización, que se pueden aplicar a otros contextos.

Palabras clave: internacionalización; educación superior portuguesa; representaciones sociales.

\section{Représentations de l'internationalisation dans un établissement d'enseignement supérieur portugais: du discours institutionnel aux voix des acteurs}

\begin{abstract}
Résumé: L'internationalisation est devenue une préoccupation majeure des établissements d'enseignement supérieur du monde entier, en tant qu'objectif dans leurs énoncés de mission et leurs programmes. Cependant, la manière dont l'internationalisation est perçue et traitée est très variée. Dans certains cas, l'internationalisation est considérée comme un service d'exportation; dans d'autres cas, l'accent est mis sur l'acquisition et le développement de compétences globales et interculturelles par les diplômés. Cet article présente une étude visant à comprendre comment l'internationalisation est perçue dans un établissement d'enseignement supérieur portugais. Pour atteindre cet objectif, des documents institutionnels ont été rassemblés et analysés et des entretiens semi-structurés ont été menés avec des responsables institutionnels, du personnel académique et non académique. Les résultats de l'analyse thématique suggèrent que l'internationalisation est considérée comme une priorité stratégique dans l'établissement associée à un ensemble d'activités (mobilité des étudiants, projets de recherche internationaux et enseignement en langue anglaise) et aux résultats souhaités (produit financier et visibilité). De plus, les personnes interrogées estiment que l'internationalisation peut être une ressource précieuse pour le développement des compétences des étudiants, en faisant preuve d'ouverture à l'égard d'initiatives telles que «l'internationalisation à domicile». Sur la base de ces résultats, des recommandations pour une approche d'internationalisation plus complète et durable, applicable à d'autres contextes, sont formulées.
\end{abstract}

Mots-clés: internationalisation; enseignement supérieur portugais; représentations sociales. 


\section{Introduction}

Internationalisation has become a major concern of higher education institutions (HEI) in recent decades, featuring as a goal in the mission statements of most universities (Proctor \& Rumbley, 2018). As globalisation has intensified, HEl have felt the need to adapt to a rapidly changing world where knowledge is created, transmitted and stored through previously unknown modalities and at speeds once unimaginable, and where new competences are required to live in globalised societies.

In this context and in the framework of the Bologna Declaration, which stresses mutual exchange of know-how and the vital role of higher education for sustainable development, internationalisation has been regarded as a strategic response to globalisation and a priority for European institutions. Yet, the ways the internationalisation of higher education is perceived and addressed differ greatly from country to country and from institution to institution based not only on priorities related to culture, history, politics and resources, but also on the beliefs of higher education stakeholders. In some cases, internationalisation is viewed as a service to export based on a "human capital" philosophy - an instrumental perspective with roots in neo-liberal education (Rizvi, 2007). In other cases, the focus falls on the acquisition and development of enhanced global perspectives and intercultural competence - an "educational" agenda (Castro, Woodin, Lundgren, \& Byram, 2016).

Recruitment of international students, international partnerships and projects, and English-medium instruction (EMI) have been reported as the most common internationalisation strategies in Europe and beyond (Altbach \& Knight, 2007; Lourenço \& Pinto, 2019). However, more recently, an increasing number of HEl have been recognising the transformational potential of internationalisation as a means to promote the development of the skills, knowledge and attitudes that will equip students to communicate effectively across cultures, work collaboratively with others, and act as responsible global citizens (Yemini, 2017). Consequently, some HEl are now engaged in designing internationalised curricula by incorporating intercultural and/or global dimensions into the programmes of study (Leask, 2015), and/or by promoting activities in domestic learning environments, for instance, through working with local cultural and ethnic groups, usually referred to as "internationalisation at home" (Beelen \& Jones, 2015).

In recent years internationalisation has gained momentum in Portuguese higher education. A visible sign was the elaboration of a set of recommendations by the Ministry of Education and Science (2014) that define a common national strategy for HEI, focused on institutional collaboration, mobility, foreign language proficiency and branding. Internationalisation is then at the forefront of academic and political debate, and Portuguese HEl are currently facing key issues about their own responses to the forces of globalisation and the pressures to internationalise. 
Against this background, this study aims to understand how internationalisation is perceived at a Portuguese Higher Education Institution both in the institutional discourse and from the point of view of key stakeholders. As suggested by Lewin-Jones (2019, p. 209), "HE's internationalisation involves discourse, with language constructing, reproducing and justifying this agenda. This is important, for the language used to articulate the purpose of universities leads to the kinds of universities and the kind of education that we shall end up with". In this study we draw on the concept of social representation (Moscovici, 1961) understood as a form of practical and lay knowledge, socially built and shared, which contributes to the construction of a common reality for a specific social group. Social representations are thought to influence discourses and practices. This suggests that an examination of institutional discourses and of the ways in which individual stakeholders appropriate these discourses and create meanings with other individuals is important in achieving a fuller picture of how internationalisation is understood and approached in a given setting.

\section{Theoretical background}

Over the past decades the international dimension of higher education has risen on the agendas of international organisations, national governments, HEl and their representative bodies. This process is often described as "mainstreaming of internationalisation", meaning that internationalisation has moved from a reactive to a proactive strategic issue (Brandenburg, Hudzik, Ota, \& Robertson, 2013). Despite this development, the internationalisation of higher education is not a recent phenomenon. Knight and de Wit (1995) outline key phases in its history that date back to the Middle Ages. During that period, and up until the Renaissance, student and scholar mobility had an important impact on higher education and society, as itinerant students brought home academic knowledge and new ideas. However, it was only in the 1990s, with globalisation creating a favourable atmosphere for international cooperation and exchange, that debates around internationalisation began to develop in higher education policy and research circles, leading to a dramatic expansion of the international activities of universities.

Internationalisation nonetheless remains a "fuzzy concept [...] hard to conceptualise and even harder to operationalize" (Ryan, 2013, p. 2). The literature shows that the concept has been understood and applied in a highly variable fashion, either as a response to globalisation, as the delivery of education to other countries through multilateral agreements and branch-campuses, or as the incorporation of international perspectives into the curriculum (see Table 1). 
Table 1. Conceptualisations of internationalisation in higher education

\begin{tabular}{|c|c|c|}
\hline Source & Definition & Focus \\
\hline $\begin{array}{c}\text { Wächter } \\
1999\end{array}$ & $\begin{array}{l}\text { "internationalisation of higher education is understood as } \\
\text { the process of integrating an international dimension into } \\
\text { the teaching and research function of a higher education } \\
\text { institution" (p. 12). }\end{array}$ & $\begin{array}{l}\text { Integration of } \\
\text { an international } \\
\text { dimension }\end{array}$ \\
\hline $\begin{array}{c}\text { van Damme } \\
2001\end{array}$ & $\begin{array}{l}\text { "internationalisation' refers to the activities of higher } \\
\text { education institutions, often supported or framed by } \\
\text { multilateral agreements or programs to expand their } \\
\text { reach over national borders" (p. 417). }\end{array}$ & $\begin{array}{l}\text { Multilateral } \\
\text { agreements; } \\
\text { cross-border } \\
\text { activities }\end{array}$ \\
\hline $\begin{array}{l}\text { Qiang } \\
2003\end{array}$ & $\begin{array}{l}\text { "Internationalization of higher education is seen as one } \\
\text { of the ways a country responds to the impact of } \\
\text { globalization, yet at the same time respects the } \\
\text { individuality of a nation" (p. 249). }\end{array}$ & $\begin{array}{l}\text { Response to } \\
\text { globalisation }\end{array}$ \\
\hline $\begin{array}{l}\text { Knight } \\
2004\end{array}$ & $\begin{array}{l}\text { "Internationalization at the national/sector/institutional } \\
\text { level is defined as the process of integrating an } \\
\text { international, intercultural or global dimension into the } \\
\text { purpose, functions or delivery of post-secondary } \\
\text { education" (p. 11). }\end{array}$ & $\begin{array}{l}\text { Integration of } \\
\text { an international } \\
\text { dimension }\end{array}$ \\
\hline $\begin{array}{c}\text { Teichler } \\
2004\end{array}$ & $\begin{array}{l}\text { "Internationalisation' [refers to] the growing border- } \\
\text { crossing activities between national systems of higher } \\
\text { education" (p. 5). }\end{array}$ & $\begin{array}{l}\text { Cross-border } \\
\text { activities }\end{array}$ \\
\hline $\begin{array}{l}\text { Altbach \& Knight } \\
\qquad 2007\end{array}$ & $\begin{array}{l}\text { "Internationalization includes the policies and practices } \\
\text { undertaken by academic systems and institutions - and } \\
\text { even individuals - to cope with the global academic } \\
\text { environment" (p. 290). }\end{array}$ & $\begin{array}{l}\text { Response to } \\
\text { globalisation }\end{array}$ \\
\hline
\end{tabular}

Source: the authors

Regardless of these different conceptualisations, Knight's (2004) definition of internationalisation as the integration of an intercultural or global dimension into teaching, research and enterprise in universities seems to have had strong resonance. However, despite scholarly agreement with Knight's definition, countries, institutions and stakeholders still hold different interpretations of internationalisation, which translate into different strategies in the development of an internationalisation agenda.

According to Knight (2004), there are six different approaches that illustrate and assess the manner in which internationalisation is conceptualised and implemented at the institutional level. These are activity approaches, which highlight the programme, such as study abroad and institutional linkages; rationales and outcomes approaches, which attach more weight to the motivations and expected results of internationalisation, namely student and staff development and increased visibility; process and at-home 
approaches, which focus on (extra)curricular and organisational aspects of HEl; and abroad or cross-border approaches, which accentuate the linkages with other countries focusing on mobility.

These approaches are related to the motivations/rationales HEl have to engage in internationalisation. Knight (2004) identified four rationales: the economic rationale sees internationalisation as a way to increase competitive edge through the development of a highly skilled and knowledgeable workforce; the political rationale relates to the country's position and role in the world, and is linked to the idea that educational cooperation can be an extension of foreign policy; the social/cultural rationale sees internationalisation as a way to promote respect for cultural diversity among and within countries, particularly through the development of students' communication skills; finally, the academic rationale is related to the aims and functions of higher education, including the need to contribute to an evolving global labour market and the need for curricula redesign to face new challenges in a globalising world.

In a similar way, Stier (2006) has identified three internationalisation representations (or ideologies) in the discourse of $\mathrm{HEl}$, which lead to different practices: "idealism", "instrumentalism" and "educationalism". Idealism draws on a normative assumption that internationalisation is good per se, highlighting global life-conditions and social injustices, inducing tolerance and respect, and offering an emancipatory worldview. Instrumentalism considers internationalisation as a viable road to profit and economic growth through the education of a large and skilful labour force for an increasingly complex and multicultural market. Educationalism recognises the personal and societal value of learning itself, regarding internationalisation as a vehicle for the promotion of critical thinking and intercultural competence.

Drawing on Stier's discourses and Knight's rationales, Woodin, Lundgren and Castro (2011) analysed the institutional documents of three universities in Spain, Sweden and the UK. They found that, although stated aims included an educationalist rationale emphasising the development of competences for employment in culturally diverse environments, the motivations behind these were clearly commercial and/or quality-driven. They concluded that internationalisation strategies are still instrumentally oriented, sustained on student mobility, strategic alliances and profile-raising initiatives.

In a second study, Castro et al. (2016) explored the discourses of internationalisation underlying the perceptions of academic staff from $28 \mathrm{HEl}$. In general, academics made explicit an underlying economic rationale and instrumentalist discourse in the internationalisation strategies of their institutions. Yet, when referring to the implementation of internationalisation, they themselves used an educational discourse sustained on a commitment to integrate into their teaching practice the personal development of their students, such as fostering open and respectful exchange of views. 
The present study takes these findings further by exploring institutional discourses and the representations of different stakeholders to analyse the significance of convergences or dissonances and their impact on a comprehensive and sustainable internationalisation policy in HE.

\section{Methodology}

The research question "How is internationalisation conceptualised and approached at the institution?" was the base for the following specific objectives: 1) identify the discourses of internationalisation present in institutional documents; 2) identify stakeholders' representations of the concept of internationalisation, its main drivers, benefits, and barriers.

The study included policy document analysis and semi-structured interviews with key stakeholders. The documents analysed were the Rector's Action Programme, the Strategic Plan and the Plan of Activities in force in 2016, the time of data collection. With a focus on stakeholders' representations, purposive sampling was used and the following people were interviewed: a Pro-Rector, a Department Director, a Coordinator of a Research Unit, a Master's Course Director, a representative of the International Office, a representative of the Erasmus Student Network (ESN), an Erasmus Department Coordinator, and three lecturers from Language Didactics, Science Didactics, and Psychology. Participants were approached via email and criteria for their selection included their role (governing and coordinating bodies, academic and non-academic staff), perspective (those who publicly expressed views of internationalisation), diversity (gender, experience, background) and, in the case of department-level participants (Directors, Erasmus Coordinator, and lecturers), their belonging to the Social Sciences, an area that is reported to be the least internationalised of this institution due to little student and staff mobility and fewer programmes in English.

The interview guide with semi-structured questions focused on five key issues in internationalisation: the concept, key drivers, perceived benefits, barriers and constraints, internationalisation of the curriculum (loC) and/or internationalisation at home (laH). Interviews lasted between 45 and 150 minutes and were conducted individually in private rooms in the participants' workplace. All interviews were recorded and transcribed. Participants were informed as to what the research entailed and how it might be used and were assured that all data would be treated anonymously and confidentially. They also signed informed consent forms with the option of withdrawing from the research at any time.

A thematic deductive approach to analysis was taken to both documents and interviews (Braun \& Clarke, 2006). For the analysis of the institutional documents we identified words and phrases that could be linked to Knight's approaches and rationales and/ 
or Stier's discourses. For instance, a phrase such as 'develop students' intercultural skills" was linked to the sociocultural rationale and an educationalist discourse. For the interviews, themes were derived from the interview topics identified above and linked to underlying discourses and rationales. Final consensus on the themes was reached through a peer debriefing process among the researchers.

\section{Results and discussion}

In a first section, we present the results of the analysis of institutional policy documents; in a second section, we bring the voices of stakeholders concerning their representations of internationalisation. Analyses are illustrated by extracts from documents and interviews that were translated from Portuguese into English.

\section{Internationalisation in institutional documents}

In institutional documents internationalisation is considered a central priority and a strategy to attract international students and increase visibility. It is approached as a set of activities that include student mobility, international projects and partnerships, and EMI. This might be explained by the fact that the number of these activities is a criterion used to assess the level of internationalisation (and therefore the quality) of under/postgraduate courses in Portuguese HEl. The following excerpt from the Rector's Action Programme illustrates these views:

Our closest attention focuses on the promotion of internationalisation in order to stimulate the increase in the number of graduate students, our main goal for the coming years. (Rector's Action Programme 2014-2018, p. 38)

A discourse on activities is often combined with outcomes, and most documents emphasise economic reasons for internationalisation, namely the need to guarantee the financial sustainability of the institution. This is related to the Portuguese context at the time, influenced by financial crisis and population decline, which contributed to the reduction of student intake in Portuguese HEl. The Rector's Action Programme and the Plan of Activities draw attention to these issues:

The plan to significantly change the number and percentage of graduate students continues. It is a plan that cautions worrying scenarios. It is associated with the goal of attracting international students and safeguarding the sustainability of the [institution name]. (Rector's Action Programme 2014-2018, p. 24) 
The promotion and support of researchers, so that they can participate in international programmes, namely Horizon 2020, is extremely important for the sustainability and consolidation of the [institution name], and as an opportunity to attract funding and the best researchers. (Plan of Activities, 2015, p. 28)

Apart from the economic rationale, there are also examples of what Knight (2004) deemed the "emerging key motivations" to internationalisation. These include a political rationale associated with strategic alliances, mainly through bi/multilateral educational agreements with Portuguese-speaking countries, and an academic rationale based on the need to establish an international profile and reputation, related to the quest for name recognition and to achieve the highest positions in international rankings. This is emphasised in the excerpt below:

To be a renowned institution, recognised as one of the best in the world, and able to attract the best researchers, is one of the main goals. (Plan of Activities, 2015, p. 36)

However, in some documents a sociocultural rationale is visible, highlighting the role that internationalisation can play in the development of intercultural skills by all students (not only a "mobile elite"), through (extra)curricular activities and in line with the principles of laH:

Internationalization further comprises greater attention to intercultural competence in foreign languages. (Strategic Plan, 2012, p. 17)

Among the multitude of facets that internationalization can take, the [institution name] will focus on [...] encouraging the development of curricula and, in general, of an international teaching and learning style, which will serve not only the international flows that the university aims to attract and retain, but also the enrichment of the experience provided to Portuguese students and researchers. (Plan of Activities, 2015, p. 36, our italics)

Nonetheless, institutional discourses follow predominantly an instrumentalist rationale, emphasizing the importance of international fee-paying students and international projects to ensure short-term financial gains.

\section{Internationalisation in the voices of stakeholders}

Internationalisation is regarded as a key issue by all stakeholders. Echoing Stier's idealism discourse, a Pro-Rector states, "internationalisation is almost like a natural state and should be a normal thing in the university". Despite this general agreement, different 
stakeholders hold different views of internationalisation. Governing and coordinating bodies tend to regard it as an "add-on" of foreign students and international projects that are useful to increase the attractiveness of the institution and bring in much needed funding:

Internationalisation is related to student mobility, university rankings, international projects. There are academic and scientific reasons for this, but mostly reasons associated with prestige and visibility, and also much needed funding. (Course Director)

Lecturers, nonetheless, seem to have a more multidimensional understanding of the term. Although they associate it mainly with student mobility, they regard it more in terms of what this mobility can bring to improve the quality of education and "bring universities closer and knowledge areas together" (Lecturer, Psychology).

Regarding the drivers of internationalisation, stakeholders believe that this is a response to the current context of globalisation and to the external pressures of both national and international organisations related, for instance, to the assessment of HEl:

[Internationalisation] has to do with issues concerning the process of globalisation that affect $\mathrm{HEl}$ around the world. There are also technical reasons associated with the assessment of HEl that privilege international work and collaboration between researchers. I would say that there is an international context, either across several areas, or, more particularly, in Higher Education, that applies pressure and explains this commitment to internationalisation. (Department Director)

In the specific case of Portugal, and coherent with the institutional documents, internationalisation is regarded both as a response to the economic and demographic crises, and a strategy to ensure the visibility of a small and peripheral university:

We are a small university in a peripheral area, sandwiched between two big universities, Porto and Coimbra. Therefore, the internationalisation of the university is the only option for its development. (International Office Representative)

Yet, when questioned about the benefits of internationalisation, stakeholders follow an educationalist discourse that sees internationalisation (understood mainly as "mobility") as a valuable asset for the development of students' transversal and foreign language skills:

Students develop competences that are mainly social and relational. Autonomy, the ability to deal with unexpected situations, resilience, apart from other learning 
possibilities, for example, learning a foreign language, the ability to connect with people from different cultures. (International Office Representative)

When confronted with the fact that not all students are able to study abroad, and, therefore, might not have the chance to develop these competences, stakeholders share alternative possibilities in line with the principles of $\mathrm{IoC}$ and $\mathrm{laH}$. These range from promoting contact with international students on campus or with foreign people in the community, participating in international projects, using ICT, and integrating intercultural skills in the curriculum:

A course unit on intercultural education should be mandatory for all students.

But there are also ways to integrate intercultural competences in the different course units. (Pro-Rector)

Whilst acknowledging the benefits, stakeholders emphasise certain barriers to successful implementation: the financial crisis, which together with the disadvantaged socioeconomic background of some students in the Social Sciences affects outgoing mobility; the lack of a collaborative culture in $\mathrm{HEI}$, understood as essential to promote international partnerships; legal constraints related to the existence of an external evaluation board that is responsible for the approval of higher education courses and limits changes to the curriculum; the lack of English language skills (students' and staff), which affects EMI, as well as the integration of incoming students; an excessive workload of academic staff, which prevents staff mobility; and lack of information and training, namely in the areas of IoC and laH. Below are some illustrative quotes:

Our students have specific characteristics related to their socioeconomic background that prevent mobility. Scholarships are not enough; it is always necessary to put in your own money and use family resources to cover expenses. (Erasmus Coordinator)

There are also legal constraints. The courses are defined by a specific model from the Ministry of Education and this framework hinders curriculum change. (Department Director)

The main problem is to understand what this [loC and laH] means, and how to do it. To achieve this, teachers need training. (International Office Representative).

Considering these findings, in the following section we propose some recommendations that might help overcome these barriers and ensure that there is a common understanding of and strategy for internationalisation at the institution. 


\section{Concluding remarks and recommendations}

Summarising our findings, we conclude that internationalisation is inscribed as a priority in the institutional policy and mission documents of the institution, where internationalisation is often associated with a set of activities (student mobility, international projects and partnerships, and EMI) or with a set of desired outcomes (increased revenues and institutional visibility). These are the manifestations of the main motivations for internationalisation which are economic, created by an urgent need to guarantee financial sustainability. However, other drivers are starting to make a timid appearance. These are related to an educationalist discourse, emphasising the development of intercultural and communication skills by all students.

The analysis of the interviews demonstrates a coherence with these findings. Stakeholders, especially from coordinating and governing bodies, have a one-dimensional representation of internationalisation, regarding it as an "add-on" of foreign students and partnerships that are useful to increase the attractiveness of the institution and bring in much needed funding. Academic and non-academic staff, for their part, signal their concern with educationalist purposes considering internationalisation as valuable in the development of students' personal and professional skills. Realising the difficulties some "home" students might have to participate in mobility experiences and develop these skills, stakeholders express general openness towards loC and $\mathrm{laH}$ and provide examples of activities that can be conducted or that they are already conducting in their classrooms. Nonetheless, they assume that these are complex concepts that need to be discussed and included in continuing professional development programmes. Besides these constraints, stakeholders identify other factors that may undermine a more sustainable and integrated internationalisation strategy: more generic threats are associated with financial difficulties, the lack of a collaborative culture among academics and the perceived lack of flexibility of curricula; specific weaknesses of the institution are the lack of English language skills of both students and staff, and the excessive workload of higher education academics.

In the light of these results, we can affirm that this HEl is at a turning point in its internationalisation agenda. Indeed, it has clearly defined priorities with respect to international openness, through recruiting students and establishing international partnerships according to an internationalisation abroad perspective, but it is starting to show concern for the intercultural education of students and the development of an inclusive environment in the campus. This is visible in the new Rector's Action Programme (2018-2022) that highlights citizenship education as the university's main function, stressing student integration as one of the biggest challenges of the institution, one that can be overcome through extending social support and promoting cultural activities. 
Yet, in order to accomplish these goals, it is important to develop a more comprehensive approach to internationalisation, one that is embraced by different institutional actors and has greater impact on student learning. Hence, acknowledging the limitations of this study in sample size, we suggest a list of recommendations for different stakeholders that may be transferable to other HEl and contribute to the development of broad-based studies with larger samples from the higher education sector, both locally and internationally (Table 2).

Table 2. Recommendations for a comprehensive approach to internationalisation

\begin{tabular}{|c|c|}
\hline Institutional actors & Recommendations \\
\hline $\begin{array}{l}\text { Rectory and Department } \\
\text { Direction Board }\end{array}$ & $\begin{array}{l}\text { - Definition of a comprehensive institutional (and departmental) vision } \\
\text { for internationalisation, both within an internationalisation abroad and } \\
\text { an laH perspective, with the indication of (short, medium and long- } \\
\text { term) goals, expected outcomes, milestones, and measures of } \\
\text { success. } \\
\text { - Revision of academic staff workload in order to include opportunities } \\
\text { for mobility and professional development, especially in the areas of } \\
\text { foreign language learning, loC and laH. } \\
\text { - Promotion and valorisation of a collaborative culture among } \\
\text { stakeholders, for instance by encouraging academics to work together } \\
\text { with the International Office and the ESN to foster student outgoing } \\
\text { mobility and intercultural exchanges. }\end{array}$ \\
\hline $\begin{array}{c}\text { Rectory and International } \\
\text { Office }\end{array}$ & $\begin{array}{l}\text { - Promotion of a campus dialogue that includes open discussion } \\
\text { sessions and dissemination of institutional documents and } \\
\text { internationalisation actions, in order to convey a common } \\
\text { understanding of internationalisation and create a pervasive } \\
\text { understanding that this is not the sole endeavour of the International } \\
\text { Office but is everyone's responsibility. }\end{array}$ \\
\hline Administrative Office & $\begin{array}{l}\text { - Official recognition of students' actions (participation in international } \\
\text { projects, organization of international and/or intercultural events, } \\
\text { volunteering abroad). }\end{array}$ \\
\hline Course Directors & $\begin{array}{l}\text { - Definition of (international) graduate attributes the university } \\
\text { community agrees its students should develop during their time with } \\
\text { the institution. These attributes should go beyond disciplinary } \\
\text { expertise to include competences required to engage in multicultural } \\
\text { societies, and should be considered when designing learning } \\
\text { outcomes. }\end{array}$ \\
\hline $\begin{array}{l}\text { Academic staff and } \\
\text { researchers }\end{array}$ & $\begin{array}{l}\text { - Development of strong and diverse international partnerships, in } \\
\text { order to facilitate staff and student exchanges, and international } \\
\text { research. }\end{array}$ \\
\hline
\end{tabular}

Source: the authors 
All of these recommendations have in common the need for HEl to understand the true meaning and goals of internationalisation and move beyond isolated activities, developing an action-oriented and institution-wide strategy that rises above the operational issues of internationalisation and addresses the substantive "international", "global" and quality mandates of higher education. This is particularly relevant at a time of increased political and social tension in several parts of the world, including Europe. Increased nationalist, religious and ideological conflicts challenge the original ideas of international cooperation and exchange in higher education as promoters of peace and mutual understanding. Therefore, it seems appropriate to recall the words of Brandenburg and de Wit (2011, p. 17) who state:

We have to dig deeper, place the options within a new set of values and rationales, and ensure that we really achieve what is meaningful. The future of higher education is a global one, and it is our job to help preparing the higher education world for this. Therefore, what we need are people who understand and define their role within a global community, transcending the national borders, and embracing the concepts of sustainability, equity of rights and access, advancement of education and research, and much more. But essentially, we need to reaffirm the core role of universities: to help understand this world and to improve our dealing with it. Called for is a common commitment at the institutional and personal level of how we and our students will be prepared to live and work in a global community.

\section{Acknowledgement}

This work is financially supported by National Funds through FCT - Fundação para a Ciência e a Tecnologia, I.P., under the projects SFRH/BPD/94768/2013 and UIDB/00194/2020.

\section{References}

Altbach, P. G., \& Knight, J. (2007). The internationalization of higher education: motivations and realities. Journal of Studies in International Education, 11, 290-305.

Beelen, J., \& Jones, E. (2015). Redefining internationalization at home. In A. Curaj, L. Matei, R. Pricopie, J. Salmi, \& P. Scott (Eds.), The European Higher Education Area: Between critical reflections and future policies (pp. 67-80). Dordrecht: Springer.

Brandenburg, U., \& de Wit, H. (2011). The end of internationalization. International Higher Education, $62,15-17$.

Brandenburg, U., Hudzik, J. K., Ota, H., \& Robertson, S. (2013). From innovation to mainstream and beyond: The unfolding story of internationalisation in higher education. In H. De Wit, F. Hunter, L. 
Johnson, \& H.-G. van Liempd (Eds.), Possible futures: The next 25 years of the internationalisation of higher education (pp. 63-78). Amsterdam: EAIE.

Braun, V., \& Clarke, V. (2006). Using thematic analysis in psychology. Qualitative Research in Psychology, 3(2), 77-101.

Castro, P., Woodin, J., Lundgren, U., \& Byram, M. (2016). Student mobility and internationalisation in higher education: perspectives from practitioners. Language and Intercultural Communication, 16(3), 418-436.

Knight, J. (2004). Internationalization remodeled: Definition, approaches, and rationales. Journal of Studies in International Education, 8(1), 5-13.

Knight, J., \& De Wit, H. (1995). Strategies for internationalisation of higher education: Historical and conceptual perspectives. In H. De Wit (Ed.), Strategies for the internationalisation of higher education. A comparative study of Australia, Canada, Europe and the United States of America (pp. 5-32). Amsterdam: EAIE.

Leask, B. (2015). Internationalizing the curriculum. Abingdon: Routledge.

Lewin-Jones, J. (2019). Discourses of 'internationalisation': a multimodal critical discourse analysis of university marketing webpages. Research in Post-Compulsory Education, 24(2-3), 208-230.

Lourenço, M., \& Pinto, S. (2019). Expatriate and home teachers' beliefs about English-medium instruction at a Portuguese university. European Journal of Higher Education, 9(3), 252-267.

Ministry of Education and Science. (2014). A strategy for the internationalisation of Portuguese Higher Education. Lisbon: MES.

Moscovici, S. (1961). La psychanalyse, son image et son public. Paris: PUR.

Proctor, D., \& Rumbley, L. E. (2018). The future agenda for internationalization in higher education: Next generation insights for research, policy and practice. Abingdon: Routledge.

Qiang, Z. (2003). Internationalization of higher education: Towards a conceptual framework. Policy Futures in Education, 1(2), 248-270.

Rizvi, F. (2007). Internationalization of curriculum: A critical perspective. In M. Hayden, J. Levy \& J. Thompson (Eds.), Research in international education (pp. 391-403). London: SAGE.

Ryan, J. (2013). Introduction. In J. Ryan (Ed.), Cross-cultural teaching and learning for home and international students: Internationalisation of pedagogy and curriculum in higher education (pp. 1-12). Abingdon: Routledge.

Stier, J. (2006). Internationalisation, intercultural communication and intercultural competence. Journal of Intercultural Communication, 11, 1-11.

Teichler, U. (2004). The changing debate on internationalization of higher education. Higher Education, $48,5-26$.

Van Damme, D. (2001). Quality issues in the internationalisation of higher education. Higher Education, $41,415-441$.

Wächter, B. (1999). Internationalisation in higher education: A paper and seven essays on international cooperation in the tertiary sector. Bonn: Lemmens. 
Woodin, J., Lundgren, U., \& Castro, P. (2011). Tracking the traces of intercultural dialogue in internationalization policies of three EU universities: towards a framework. European Journal of Higher Education, 1(2-3), 119-134.

Yemini, M. (2017). Internationalization and global citizenship: Policy and practice in education. Cham, Switzerland: Palgrave Macmillan.

\section{Mónica Lourenço \\ Universidade de Aveiro, CIDTFF (Portugal) \\ Email: monicalourenco@ua.pt}

Orcid: https://orcid.org/0000-0002-8124-2452

Ana Isabel Andrade

Universidade de Aveiro, CIDTFF (Portugal)

Email: aiandrade@ua.pt

Orcid: https://orcid.org/0000-0002-3182-9351

Michael Byram

Durham University (United Kingdom)

Email: m.s.byram@durham.ac.uk Orcid: https://orcid.org/0000-0003-1116-2366

Correspondência

Mónica Lourenço Universidade de Aveiro, Departamento de Educação e Psicologia Campus Universitário de Santiago, 3810-193 Aveiro, Portugal

Data de submissão: Março 2019

Data de avaliação: Junho 2019

Data de publicação: Maio 2020 